〔36〕ポリアクリロニトリル系樹脂の表面イミノェーテル化 および表面イミドイルハロゲン化反応と生成物の性質

(1964 年 10 月 5 日受理)

田附重夫*・林 晃一郎**・岡村誠三**

\begin{abstract}
要旨ポリアクリロニトリルまたはその共重合物中のニトリル基は 無水の条件下でアルコール-塩化 水素混合物または八ロゲン化水素と反応して容易にイミノエーテルあるいは塩化イミドイルを生成することを 見出した。この反応は不均一系で進行し, 反応は反応試薬のポリマー中への拡散によって支配されるようであ

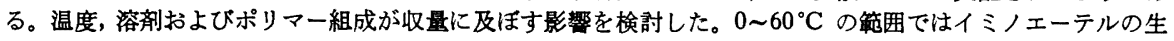
成は高温ほど良く進むが, 塩化イミドイルの生成は $25^{\circ} \mathrm{C}$ に反応速度の最大值を有する。この反応をアクリル 系合成絨維の改兵に応用した。イミノエーテル化または塩化イミドイル化処理をしたアクリル繊維は原料繊維 に比へて非常に帯電しにくい。また, 染色性も改善され, 染色性と染料中の官能基の関倸を論じた。アクリル 繊維の機械的性兵はこの処理により影锌されない。しかしながら，この処理法により導入された官能基は容易 に加水分解されてアミドまたはカルボン酸になるためこの処理効果は加水分解により若干減ずる。
\end{abstract}

\section{1. 緒言}

ニトリル基よりイミデートを誘導する反応はすでに 19 世紀末に Pinner 合成 ${ }^{1)}$ として見出されている。この 反応の応用は広く，僅少の例外を除いて多くの脂肪族お よび芳香族ニトリルに適用できるが，ポリアクリロニト リルに応用された例は文献に見られない。

本報告ではポリアクリロニトリル (PAN) およびその 共重合物を不均一系にて塩化水素ーアルコール混合物, ま たは八ロゲン化水素単独にて処理し，表面のみをイミ， エーテルまたは八ロゲン化イミドイルとする反応を検討 した。このようにして改質された PAN は,イミノェー テル基または八ロゲン化イミドイル基の反応性のため新 しい性翼が期待される。

\section{2. 実験}

\section{1 試 薬}

原料 PAN および共重合物は乳化重合にて 調整した ものを粉末として使用した。PAN (エクスラン) 布は市 販のものを十分洗浄して用いた。

使用せるアルコール中, メタノールおよびェタノール は金属マグネシゥムにて脱水後精留した。第三級ブタノ ールは市販最純品をそのまま用いた。

塩化水素ガスおよび臭化水素ガスは濃硫酸に濃塩酸ま たは濃臭化水素酸を滴下し, 発生するガスを濃硫酸, 塩 化カルシウムにて乾燥し反応に供した。

\section{2 反応操作}

ガラス製反応器はトラップ型でガス吹込み口および排 出口を備えており, それぞれの口はガラスコックにて外 部としゃ断されている。この容器にドライボックス中に

* 生産開発科学研究所(京都市左京区下鴨森本町 15)

** 京都大学工学部高分子化学教室(京都市左京区吉田泉殿町)
て原料ポリマーおよびアルコール（イミノェーテル化の 場合) を加え, 所定時間, 所定温度にて 乾燥塩化水素が ス(または臭化水素ガス)を吹込み，反応せしめる。イミ ノェーテル化反応の場合は反応後ポリマーをロ別, ただ ちに減圧乾燥する。八ロゲン化イミドイル化反応の場合 は反応容器の一方のコックより減圧にし, 未反応八ロゲ ン化水素を除く。

\section{3 反応生成物の分析 \\ 2.3.1 反度度の測定}

反応生成物を過剩の $0.1 N$ 水酸化ナトリウム水溶液 に懸濁せしめ, $0.1 N$ 塩酸にてフェノールフタレインを 指示薬として逆滴定して生成物中の八ロゲン化水素量を 求め, 反応度を算出した2”。

\section{3 .2 赤外吸収スペクトル}

日立 EPS $2 U$ 型赤外分光光度計にて臭化カリウム錠 剤法により測定した。

\section{3. 結果および考察}

\section{1 ハロゲン化イミドイル化反応}

3.1 .1 ハロゲン化イミドイル化反応の時間-収率曲線 PAN $0.5 \mathrm{~g}$ を半径 $4 \mathrm{~cm}$, 長さ $15 \mathrm{~cm}$ の反応容器に 入れ乾燥, 塩化水素ガス, または乾燥臭化水素ガスを吹 込み密閉して反応せしめた場合の時間一収率曲線を Fig. 1 に示す。

反応は気相, 固相の界面で起こるゆえ, 拡散支配の可 能性が大きい。固相中を低分子のガスが拡散し反応する のであるから次に述ベるイミノェーテル化に比べれば拡 散過程は容易と思われる。反応温度を適当に選べば反応 率は飽和することなく増加する。反応に最適温度が存在 することは (1) 式に示すような平衡が存在することを推

$$
\mathrm{RCN}+\mathrm{HCl} \leftrightarrows \mathrm{RC}=\mathrm{NH}
$$




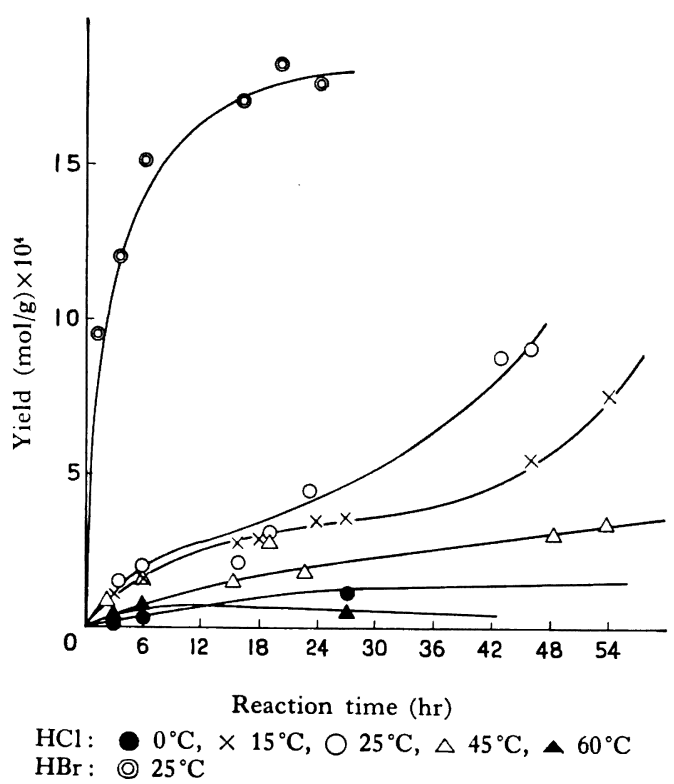

Fig. 1. Time-yield curve of the reaction between

PAN and $\mathrm{HCl}$ or $\mathrm{HBr}$ at different temperatures.

測せしめる。

高温では平衡が左にずれるため収率には飽和現象が認 められる。これに反し $0,15,25^{\circ} \mathrm{C}$ の反応温度では時 間一収率曲線は単調に増大しており，45 および $60^{\circ} \mathrm{C}$ の 時間-収率曲線とは形が異なることを注意すべきである。 臭化水素を用いた反応は塩化水素に比べて約 4 倍速い。

\subsection{2 塩化水素ガス吹込み方法の影翌}

反応が拡散支配である場合は気相中の塩化水素濃度は 反応速度に影響しないはずである。これを確かめるため 塩化水素ガスの吹込み方法を, 反応中常時吹込み，反応 初期のみ吹込み，一定時間ごとの吹込み，と種々変化せ しめて反応率を測定した結果を Fig. 2 に示した。

吹込み方法は反応率に影響せず，この事実は拡散支配

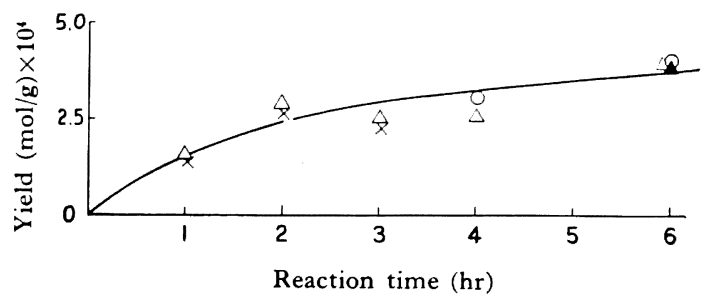

$x$ : Feeding continuously, $\triangle$ : Feeding during initial $5 \mathrm{~min}, \mathrm{O}$ : Feeding for $5 \mathrm{~min}$ after $2 \mathrm{hr}$ in addition to the initial feeding, $\Delta$ : Feeding for $5 \mathrm{~min}$ each after 2 and $4 \mathrm{hr}$ in addition to the initial feeding

Fig. 2. Effect of conditions of feeding $\mathrm{HCl}$ gas on the yield of imidoyl chloride at $20^{\circ} \mathrm{C}$.
の考えと矛盾しない。

\subsection{3 溶剂の影整}

エーテルおよびベンゼン中に PAN を懸濁せしめ, 塩 化水素を吹き込み塩化イミドイル化を試みた結果を Fig. 3 に示した。いずれの場合も反応率は気相の場合に比べ て低下している。

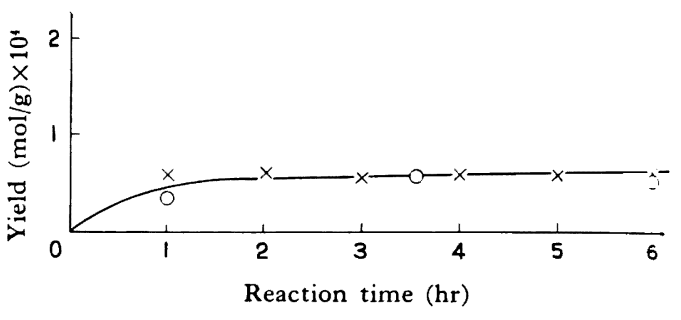

$X: 0.5 \mathrm{~g}$ of PAN suspended in $50 \mathrm{ml}$ of ether at $0^{\circ} \mathrm{C}, \quad \bigcirc: 0.5 \mathrm{~g}$ of PAN suspended in $10 \mathrm{ml}$ of benzene at $25^{\circ} \mathrm{C}$

Fig. 3. Effect of solvent on the yield of imidoyl chloride.

\subsection{4 ポリマー組成, 粒度の影響}

PAN ホモポリマーの代わりに DMF-水系より共沈殿 して調製した PAN-ポリ酢酸ビニルのブレンド物, ANVAc の共重合物および粒度の異なる試料を用いた場合 の塩化イミドイル化反応の結果を Fig. 4 に示した。

共重合物とブレンド物では反応性に大差が認められ る。隣接基効果, 表面性の変化, 拡散速度の変化など考

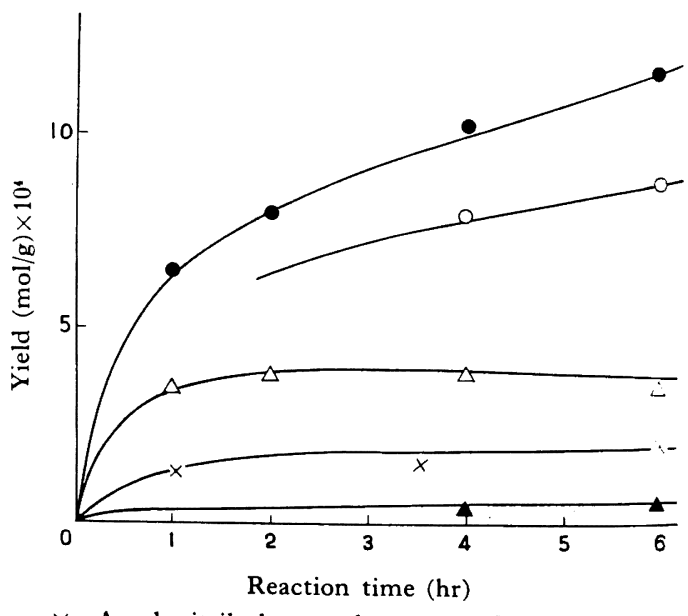

$X$ : Acrylonitrile homopolymer, $\bigcirc$ : Blend polymer (PAN/PVAc 11/1) grain size smaller than 50 mesh, - Blend polymer (PAN/PVAc 11/1) grain size bigger than 50 mesh, $\triangle$ : Blend polymer (PAN/PVAc $4 / 1$ ), $\Delta$ : AN-VAc copolymer (AN-VAc 22/1)

Fig. 4. Effect of polymer composition on the yield of imidoyl chloride at $20^{\circ} \mathrm{C}$. 
虑すべき因子は，多く結論は下せないがブレンド物の場 合少量の PVAc を混合することによりPAN の結晶構造 を破壊して反応を容易にする効果が考えられる。PVAc 量が増すとニトリハ基の含有量が減少し，したがって反 応率も低下する。

粒度の差, すなわち 表面積の 差も定性的ではあるが, 明確に反応速度に影響することが認められる。

\section{2 イミノェーテル化反応}

\subsection{1 温度の影響}

PAN (エクスラン) 布を用いて行なったイミノェーテ ル化反応の結果を Fig. 5 に示す。

$0 \sim 60^{\circ} \mathrm{C}$ の温度範囲では塩化イミドイル化反応の場合 と異なり, 高温ほど反応が良く進む。このことはおそら くイミノェーテル基が塩化イミドイル基に比べて安定で 高温でも逆反応が起こりにくいためであろう。

\subsection{2 アルコールの種類の影響}

Fig. 6 に示すごとくメタノールが最高の収率を与え, かさ高いアルキル基を有する第三級ブタノールでは反応 はほとんど進行しない。

\section{3 赤外吸収スペクトル}

3.3.1 塩化イミドイル化およびイミノェーテル化 PAN

原料 PAN, 塩化イミドイル化 PAN およびイミノェ ーテル化 PAN の IR スペクトルを Fig. 7 に示す。塩 化イミドイル化 PAN は $1690 \mathrm{~cm}^{-1} に$ に, イミノェーテ

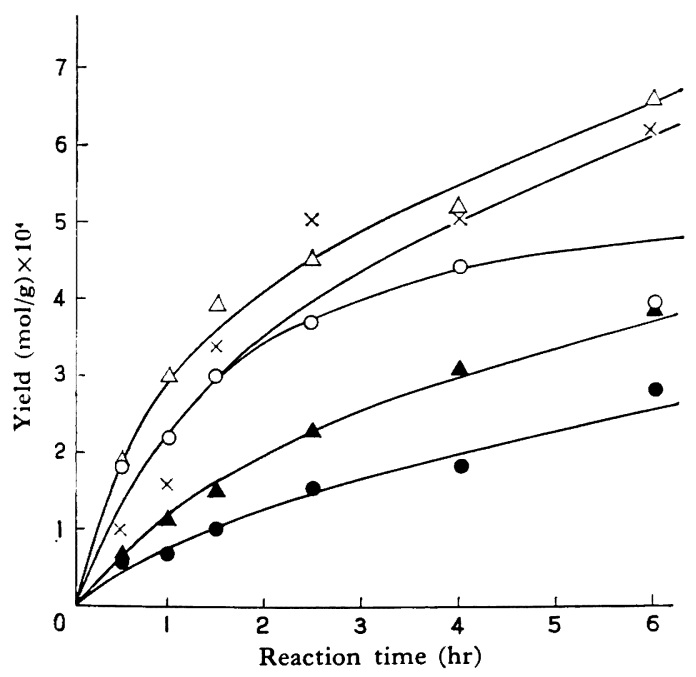

Reaction conditions: PAN (as X-lan fiber( $\mathrm{L}$ type)) $0.4 \mathrm{~g}$ immersed in methanol

$\mathrm{HCl}$ gas was introduced in the reaction vessel for $3 \mathrm{~min}$. $: 0^{\circ} \mathrm{C}, \quad \wedge: 20^{\circ} \mathrm{C}, \quad \times: 30^{\circ} \mathrm{C}, \quad \bigcirc$ : $45^{\circ} \mathrm{C}, \triangle: 60^{\circ} \mathrm{C}$

Fig. 5. Time-yield curve of iminoetherification at various temperatures.

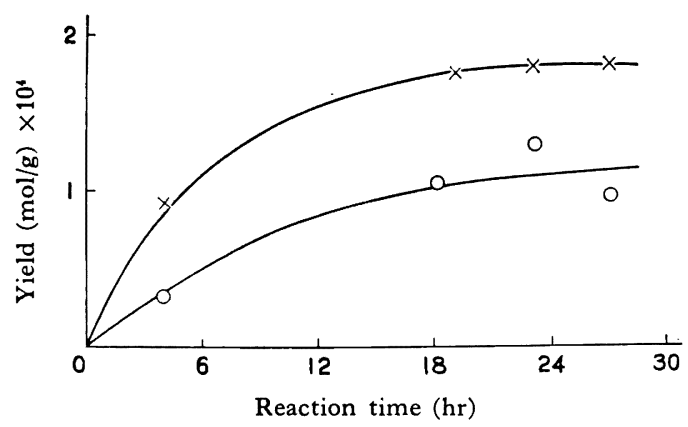

$0.5 \mathrm{~g}$ of PAN (homopolymer) in $5 \mathrm{ml}$ of alcohol $\mathrm{HCl}$ bubbled for about $3 \mathrm{~min}$.

$\bigcirc$ : Ethyl alcohol, $x$ : Methyl alcohol

Fig. 6. Dependence of yield of imidate on the kind of alcohol at $18^{\circ} \mathrm{C}$.

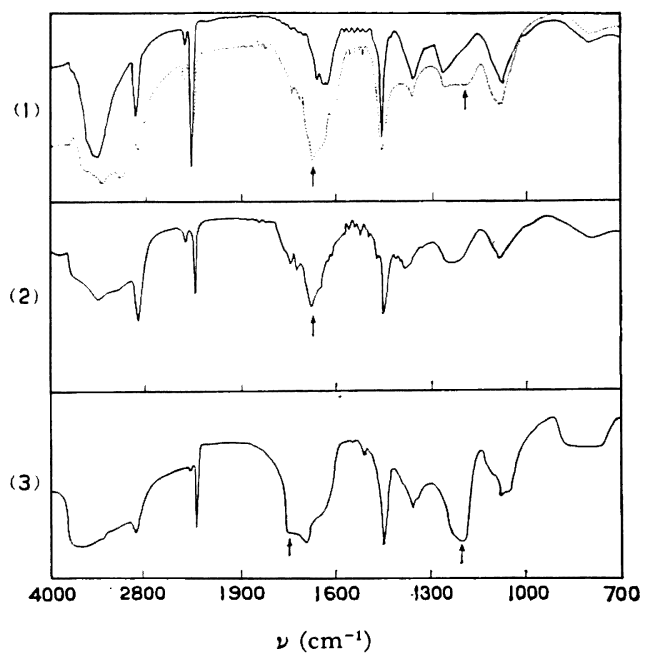

Dotted line of (1): Imidate, (2): Imidoyl chloride, (3): Imidate after hydrolysis, Real line of (1): Original polyacrylonitrile

Fig. 7. Infrared absorption spectra of imidate, imidoyl chloride, and imdate after hydrolysis in comparison with original polyacrylonitrile.

ル化 PAN は $1670 \mathrm{~cm}^{-1}$ に強い吸収を示す。これはイ ミノ結合に起因するものであろら。イミノェーテル化物 と塩化イミドイル化物の IR スペクトルは非常に良く似 ているが，前者は $1200 \mathrm{~cm}^{-1}$ 付近にェーテル基による と考えられる吸収を有している。

\subsection{2 加水分解後の IR スペクトル}

イミノェーテル基および塩化イミドイル基は容易に加 水分解されることが知られている。塩化イミドイル化 PAN を加水分解したものの IR スペクトルを Fig. 7 に 示す。 $1740 \mathrm{~cm}^{-1}$ および $1220 \mathrm{~cm}^{-1}$ の吸収よりカルボ 
Table. 1. Electric charge on X-lan fiber.

\begin{tabular}{|c|c|c|c|c|}
\hline & & $\begin{array}{l}\text { Charged voltage } \\
\text { (volt) }\end{array}$ & $\begin{array}{l}\text { Half time } \\
(\min )\end{array}$ & $\begin{array}{c}\text { Surface resistance* } \\
\log (\mathrm{ohm})\end{array}$ \\
\hline 1 & Untreated X-lan & 1640 & 11.26 & 12.2 \\
\hline 2 & Imidate & 62 & 0 & 9.39 \\
\hline 3 & Imidoyl chloride & 117 & 0 & 10.5 \\
\hline 4 & Imidoyl chloride after hydrolysis & 1610 & 5.00 & 12.2 \\
\hline 1 & \multicolumn{4}{|l|}{ Commercial X-lan (L-type) } \\
\hline 2 & \multicolumn{4}{|c|}{ Degree of iminoetherification $6.45 \times 10^{-4} \mathrm{~mol} / \mathrm{g}$} \\
\hline 3 & \multicolumn{4}{|c|}{ Degree of conversion to imidoyl chloride $4.40 \times 10^{-4} \mathrm{~mol} / \mathrm{g}$} \\
\hline 4 & \multicolumn{4}{|c|}{3 was boiled in hot water for $1 \mathrm{hr}$} \\
\hline
\end{tabular}

* Logarithum of reduced value for $1 \times 1 \mathrm{~cm}$ test piece.

ン酸が生成していることが認められる。イミノェーテル 化物を加水分解した場合も IR スペクトルは定性的に等 しい。なお同じ条件下で PAN は加水分解されない。

\section{4 イミノェーテル化および塩化イミドイル化物の 性質}

3.4.1 帯電防止効果

AATCC 法により原料ェクスラン布, イミノェーテル 化物, 塩化イミドイル化物およびその加水分解物につき 帯電試験を行なった結果を Table 1 に示す。

イミドェーテルは塩酸塩として存在し，また塩化イミ ドイルもニトリル基の塩酸塩と考えられる。この塩酸塩 が帯電防止にあずかっているのであろう。したがって加 水分解後は帯電防止能が低下寸る。本処理方法は耐水性 がわるいことが久点であり，アミン類との反応によりア ミジン結合を誘導して安定化を計ったが好結果は得られ なかった。

\section{4 .2 染色性}

イミノェーテル化ェクスラン布の染色を次の条件で行 ない, 原料エクスラン布と比較した。

\begin{tabular}{|c|c|c|c|}
\hline 染 & 助 & $\left.{ }^{\text {温 }}{ }^{\circ} \mathrm{C}\right)^{\circ}$ & 浴 \\
\hline $\begin{array}{l}\text { Acid Red PG } \\
\qquad 30 \%\end{array}$ & $\mathrm{HCOOH} 2 \%$ & 80 & $1: 1000$ \\
\hline $\begin{array}{l}\text { Aizen Cathilon } \\
\text { Pink FGH } 30 \%\end{array}$ & $\begin{array}{r}\mathrm{CH}_{3} \mathrm{COONH}_{4} \\
4 \%\end{array}$ & 80 & $1: 1000$ \\
\hline $\begin{array}{r}\text { Aniline Yellow } \\
30 \%\end{array}$ & $\begin{array}{r}\mathrm{CH}_{3} \mathrm{COONH}_{4} \\
4 \%\end{array}$ & 80 & $1: 1000$ \\
\hline
\end{tabular}

いずれも綫維重量に対する％

染色したサンプルの一定量をジメチルホルムアミド (DMF) に溶解し，末染色サンプルの同量を溶解した DMF をブランクとして, Acid Red PG の場合は $510 \mathrm{~m} \mu$ $(\epsilon=22.5 \mathrm{l} / \mathrm{g} \cdot \mathrm{cm})$, Aizen Cathilon Pink FGH の場合は
$540 \mathrm{~m} \mu(\epsilon=37.0 \mathrm{l} / \mathrm{g} \cdot \mathrm{cm})$, Aniline Yellow の場合は $425 \mathrm{~m} \mu(\epsilon=59.0 \mathrm{l} / \mathrm{g} \cdot \mathrm{cm})$ における吸光度を測定して染 着量を決定した。Fig. 8 は時間-染着量曲線である。

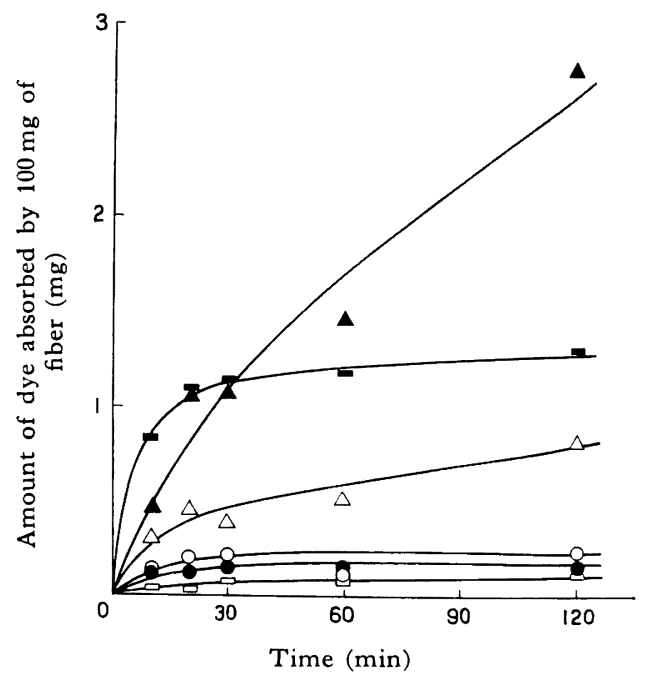

$\triangle:$ Acid Red PG +X-lan (L-type), $\Delta$ : Acid Red PG+iminoetherified X-lan, $O$ : Aizen Cathilon Pink FGH+X-lan, : Aizen Cathilon Pink+FGH +iminoetherified X-lan, $\square$ : Aniline Yellow + $\mathrm{X}$-lan, $\square$ : Aniline Yellow +Iminoetherified X-lan Degree of immonoetherification $3.94 \times 10^{-4}(\mathrm{~mol} / \mathrm{g})$

Fig. 8. Dyeability of iminoetherified X-lan fiber.

使用した 3 種の染料は次のものである。

Acid Red PG (C.I. Acid Red 85, C.I. 22245 大 日本インキ製造株式会社)

Aizen Cathilon Pink FGH (C. I. Basic Red 13, C. I. 48020 保土谷化学工業株式会社)

Aniline Yellow（東京化成工業株式会社特級試薬） なお, Aniline Yellow は通常 $p$-アミノアゾベンゼン 
Table 2. Mechanical properties of iminoetherified X-lan fiber.

\begin{tabular}{l|c|c|c|c|c}
\hline & $\begin{array}{c}\text { Denier } \\
(\mathrm{d})\end{array}$ & $\begin{array}{c}\text { Tensile strength } \\
\text { in dry (g/d) }\end{array}$ & $\begin{array}{c}\text { Tensile strength } \\
\text { in wet (g/d) }\end{array}$ & $\begin{array}{c}\text { Elongation in } \\
\text { dry (\%) }\end{array}$ & $\begin{array}{c}\text { Elongation in } \\
\text { wet (\%) }\end{array}$ \\
\hline Untreated X-lan fiber & 127.7 & 1.85 & 1.42 & 19.5 & 21.1 \\
Iminoetherified X-lan fiber & 133.5 & 1.57 & 1.43 & 21.5 & 23.5 \\
\hline
\end{tabular}

のことであるが, Aniline Yellow の商品名のこの試薬 は

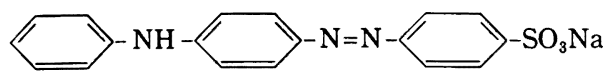

の構造を有している。

イミノェーテル化処理によりポリマー表面の物理的性 質も変わるであろう。また, 染色操作中イミノェーテル 基は加水分解を受けてアミド，カルボン酸を生成するこ とも考えられるので, 染色性に現われた差がイミノェー テル基のみに起因するとはいいがたい。しかし，上記の 3 種の染料のうち, スルホン基を有する Acid Red PG, Aniline Yellow はイミノェーテル化処理により染色性 が増大する。

$$
\text { スルホン酸がイミノェーテル基と } \stackrel{-\mathrm{C}-\mathrm{OCH}_{3}}{\mathrm{NH}_{2}+\mathrm{FSO}_{3}-}(\mathrm{F} \text { は }
$$

染料)のような塩を形成するとして説明される。一方, 第 四アンモニウム塩基を有する Aizen Cathilon Pink FGH ではイミノェーテル基と $\mathrm{R}_{\mathbf{4}} \mathrm{N}^{+} \mathrm{Cl}^{-}$の間に親和力のない ことは当然, 予想される。この場合は原料エクスランの 方が染着量が大きい。

\subsection{3 綪維性能}

イミノェーテル化度 $1.74 \times 10^{-4} \mathrm{~mol} / \mathrm{g}$ のエクスラン 布につき行なった䋊度, 強度, 伸度測定の結果を原料ェ クスランと比較して Table 2 に記した。
繊度がイミノェーテル化により約 $5 \%$ 増えている。し たがって繊維全体としての乾強度は処理により約 $10 \%$ 減, 湿強度は $5 \%$ 増となるが, 纎維の力学的性能の変化 はほとんどないといえる。

\section{4. 結論}

ポリアクリロニトリルおよび共重合物が容易にイミ， エーテル化またはイミノ八ロゲン化されることを見出 し，これをニトリル基を含有する高分子物質の改質に応 用し，反応条件の検討を行なった。本処理により機械的 性質はほとんど影響されないが，染色性改善および帯電 防止に著しい効果が認められた。しかし，イミノェーテ ル基および八ロゲン化イミドイル基はともに加水分解を 受けやすく，処理効果の耐水性に問題が残る。

付 記：本報告の一部浽日本化学会第 17 年会 (1964 年) に て発表した。なお，実験に協力いただいた中邑明子氏および帯 電試験を お願いした 京都市立染織試験所の 長峰秋夫氏に 感謝 します。

$$
\text { 文献 }
$$

1) A. Pinner, F. Klein: Ber., 10, 1889 (1877); A. Pinner: "Die Imidoäther und ihre Derivate", (1892) Oppenheim, Berlin

2) M. J. Hunter, M. L. Ludwig: J. Am. Chem. Soc., 84, 3491(1962)

\title{
Formation of Imidate and Imidoyl Chloride on the Surface of Homo- and Copolymers of Acrylonitrile and Some Properties of the Products
}

\author{
By Shigeo Tazuke*, Koichiro Hayashi** and Seizo Okamura**
}

Nitrile group of homo- or copolymer of acrylonitrile was found to be converted to imidate or imidoyl halide under unhydrous condition by reactions with alcohol-hydrogen chloride mixture or with hydrogen halide respectively. The reaction proceeded heterogeneously and seemed to be controlled by diffusion of the reactants into polymer.

The effects of temperature, solvents and polymer composition on the yield were investigated. Conversion of nitrile to imidate was favoured at higher temperature within the temperature range between $0^{\circ} \mathrm{C}$ and $60^{\circ} \mathrm{C}$, whereas formation of imidoyl chloride proceeded with the

\footnotetext{
* Research Institute for Production Development (Shimogamo-morimoto-cho, Sakyo-ku, Kyoto)

** Department of Polymer Chemistry, Faculty of Engineering, Kyoto University (Sakyo-ku, Kyoto)
} 
maximum yield at $25^{\circ} \mathrm{C}$.

These reactions were then applied to modify acrylic fibres. The imidate or imidoyl chloride of acrylic fibres showed very small electric charge in comparison with the original fibres. The dyeability of the fibres was also modified very much. Correlation between dyeability and functional groups in the dyestuff was discussed. Mechanical properties of the acrylic fibres were not affected much by this modification. However, the functional groups introduced by this modification were easily hydrolysed to amide or carboxylic acid, and therefore the effects of the modification decreased to a certain extent after hydrolysis. 